\title{
ETIKA
}

\section{ÉS EMBERIERŐFORRÁS-MENEDZSMENT: EGY RÉGI/ÚJ KAPCSOLAT?}

Az emberieróforrás-menedzsment és a gazdaságetika kapcsolatának gyökerei mélyre nyúlnak: a két terület összekapcsolódása igazából az utóbbi 15 évben kezdett önálló területté formálódni, és legalábbis kis mértékben az érdeklődés fókuszába kerülni. A szerző tanulmányában elôször összefoglalja azokat a fó impulzusokat, amelyek következtében az emberierơforrás-menedzsment etika iránt megélénkült az érdeklődés napjainkban, majd bemutat néhány olyan elemzési szintet és hozzá köthető vizsgálatot, amely azt a témát járja körül, hogy mikor és mitốl etikus vagy etikátlan az emberierôforrás-menedzsment.

Kulcsszavak: etika, emberierôforrás-menedzsment, felelốs emberierôforrás-menedzsment, emberieróforrás-menedzsment etika

„Mutass nekem egy gondoskodó kapitalistát, és én mutatok egy vegetáriánus cápát" - utal kissé szkeptikusan Karen Legge (1998) a modern szervezetekben az emberierőforrás-menedzsment területén jelentkezô egyik alapvetố etikai ellentmondásra, az emberi lények pusztán erőforrásként való kezelésére. De miért tekinthetố ez egyáltalán etikai dilemmának? Alapvetóen mit jelenthet egyáltalán az etika, az etikus viselkedés a munkavállalók kezeléséhez kapcsolódó funkcionális területen, az emberierőforrás-menedzsment tevékenységben?

Írásomban ezt a kérdéskört szeretném körüljárni: először összefoglalom azokat a fő impulzusokat, amelyek következtében az emberieróforrás-menedzsment etikai vetületei fókuszba kerültek napjainkban, majd bemutatok néhány elemzési szintet, és hozzá köthetô vizsgálatot, amely azt a témát járja körül, hogy mikor és mitól etikus vagy etikátlan az emberierôforrás-menedzsment. ${ }^{1}$

\section{EEM és a gazdaságetika kapcsolata}

$\mathrm{Az}$ emberieróforrás-menedzsment (továbbiakban $\mathrm{EEM}^{2}$ ) és a gazdaságetika kapcsolatának gyökerei mélyre nyúlnak, de a kettô igazából az utóbbi 15 évben kapcsolódott össze, kezdett önálló területté for- málódni, és (legalábbis kis mértékben) az érdeklődés fókuszába kerülni. Ennek jeleként az etika a munkahelyen, az EEM-etika, etikus EEM-témákban könyvek (Johnson, 2007) és esszégyújjtemények jelentek meg (Parker, 1998; Deckop, 2006; Pinnington et al., 2007; Bolton - Houlihan, 2007), elméleti szakcikkek és kutatási eredmények bukkantak fel vezetó gazdaságetikai és emberieróforrás-menedzsment folyóiratokban (Journal of Business Ethics, Personnel Review, Human Resource Management Review). Az EEM és az etika összekapcsolódása megjelent az oktatásban is: Wooten (2001) összefoglalójában rámutat, hogy egyes EEMtankönyvek már az 1990-as évek elején is szót ejtettek jellegzetes etikai dilemmákról, elsôsorban az emberi jogok szempontrendszerére építve: ilyen jellemző témák voltak például a munkaügyi kapcsolatok etikai kérdései, a személyes adatok védelme az EEM-tevékenységek folyamatában, vagy a kiválasztási tesztek etikai aspektusai. Más szerzók, rendszerezett módon, minden fejezet végén kitértek az adott terület etikai dilemmáira; ezt a megoldást követik Bokor és munkatársai (2007) is. Az is elófordul, hogy EEM-tankönyvekben a szerzốk egész fejezetet szentelnek etikai témáknak, például (Torrington - Hall, 1998; De Cieri - Kramar, 2005; Cascio, 2009; Redman - Wilkinson, 2009). 
Annak okai között, hogy a terület legalábbis mérsékelten a fókuszba került, fontos szerepet játszhatnak XX. század végének és a XXI. század elejének gazdasági, társadalmi tendenciái, a szervezeti múködésben,
illetve speciálisan az EEM-tevékenységben gyökerezô okok. Az elmúlt 20 évben a vállalatok gazdasági felelôssége, az etikus gazdasági múködés dilemmái egyre inkább az akadémiai és társadalmi érdeklódés fókuszába kerültek. Pusztán ennek a tendenciának hatására, a szervezeten belül az egyes funkcionális tevékenységekkel kapcsolatban - így a marketing, beszerzés, ségekkel kapcsolatban - 1gy a marketing, beszerzés, termelés tentletci mellett az EEM-ben is - felmerültek utolsó 15 ev ngy vállalat botrányai okán inkább vâllalatok topn viteli terület felelôssége került az érdeklódés középpontjába, könnyen belátható, hogy ezeknek a szervezeteknek a szervezeti kultúrája, EEM-rendszerei (pl. teljesítményértékelési és kompenzációs rendszer, vag a belsố kommunikáció) a háttérben elő́segíthették, legalábbis nem tudták meggátolni ezeket a morális félrecsúszásokat.

A vállalati felelósségvállalás gondolatkörében alapvetố a vállalat érintettjeinek számbavétele, amelyek között jelen vannak a munkavállalók is, azaz a vállalati felelősség fogalmát velük kapcsolazaz a

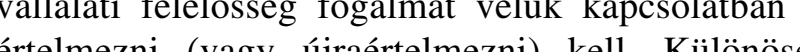
fontos lehet ez azoknak fontos lehet ez azoknak a globális vállalatoknak az esetében, anelyek gyakran tobb tízezer munkaválalót alkalmaznak, EeM-rendszercik és (elbocsátási, áttelepülési) döntéseik közvetlenül érintik nemcsa munkavállalóikat, hanem ezek családjait is, alapvetố befolyásolva életminôségüket, jólétüket, boldogságukat, ezen keresztül jelentốs hatásuk lehet a helyi kozösségekre és a társadalom egészére (Wiley, 1998). A társadalmi felelősségvállalás témakörét komolyan vevố elméleti és gyakorlati szakemberek számára az EEM-tevékenység etikussága alapvetően meghatározza az egész vállalati etikusságot. Emellett az is elég egyértelmú, hogy a globális vállalatoknál - amelyek idônként egyes országoknál is nagyobb befolyás bo birnak - ez a megnóvekedett hatalom sokszor nem jấ felelốs viselkedéssel.

A szervezeten belül a vállalati felelósségvállalással, etikus múködéssel kapcsolatos feladatok koordinációja egyes vállalatoknál az EEM-területhez került (máshol viszont PR, minôségbiztosítási, jog területnél vagy onálló szervezeti pozícióban találha juk). Más esetben csak a konkrêtan EEM-hez kötődo programok felelőssége található az EEM-területen (például diverzitás, egészségfejlesztés, önkéntesség, megváltozott munkaképességú program etc.). Egyes szerzők azt hangsúlyozzák, hogy a heterogén szervezeti megoldások ellenére az EEM-t számos esetben a szervezet lelkiismeretének (Wiley, 1998), a munkavállalókhoz kapcsolódó etikusság központjának tekintik, etikai bajnoknak, az etikai ügyek felelósének tartják (Greenwood, 2007). Ezeknek a külső elvárásoknak következtében a terület elméleti és gyakorlati képviselőinek el kell gondolkodni azon, hogyan járul hozzá az EEM a szervezeti szintü etikai kérdések megoldásához, milyen alapelvek mentén értelmezhetố saját terülez, milyen alapelvek

Párhuzamos - de az elóző jelenségektől nem fügetlen - tendenciaként jelentkezik, hogy számos országban (köztük Magyarországon is) egyre inkább sökken a munkavállalói kollektív érdekképviselet, a szakszervezetek szerepe és befolyása, átalakul (és redukálódik) a munkavállalók törvényi védelme (példa erre Magyarországon a munkaügyi perek költségtérí tésének megjelenése). Ezt a (globálisnak tekinthetô) jelenséget Greenwood (2007) a kollektivizmus és a munkavállalói érdekérvényesités háttérbe szorításaként jellemzi. Azt állítja, hogy a munkavállalók kollektív véleménynyilvánításának, bevonásának szerveeti (és társadalmi szinten egyaránt jellemzố) elfojtósa lecsökkenti a mu savállalók védekezóképesś́ćt, tovább eóti az indive (ála âllalatoknak (es az EEM-funkciónak) egyre nagyobb

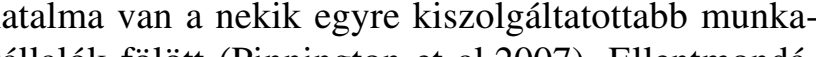
(20) Ellentmondáos, hogy a puha EEM retorikájában a munkavállalók eevonása, az „empowerment” egyre hangsúlyosabban jelen van, ám - ahogy Legge (1998) rámutat - a puha EEM sokszor „,báránybớrbe bújtatott farkas”. Azaz a valóságban sokszor a bevonás álarca mögött a szervezeti kultúra manipulálásával átalakítják, korlátozzák es kihasználják a munkavállalókat. Emellett, ha feltéelezzük, hogy a puha EEM valódi bevonást jelenthet, ennek ,élvezete” akkor csak a munkavállalók csekély részét illeti meg. általában a jól kvalifikált, piacképes 作 rtásában kulcsfontosságú munkavállalóknak van erre esélye, addig a nagy tömeget alkotó, kevéssé képzett, "onnyen helyettesíthetó, ebben a logikában „kevésbê (vagy akár mondjuk a call centerben dolgozó adminisztratív munkaerónek) incs.

Ehhez kapcsolódva fontos megemlíteni, hogy a munkavállaloi kapcsolatok témaköre már régen jelen van a gazdaságetikai diskurzusokban. A világ számos részén, többek között az USA-ban, Európa nagy részén és Ausztráliában is, beszélhetünk a munkavállalói viszony alapvetó átalakulásáról. A határozatlan idejű, stabi foglalkoztatási formák mellett egyre inkább elterjedtek a változó, ideiglenes, rövid távú szerződéseken alapulo, tranzakciós jellegú munkavégzési formák. Növekszik munkaeró-kölcsönzés jelentősége (fehér és kék gallérosoknál egyaránt), a (nem feltétlenül önkéntes) önfogla koztatás részaránya. Összességében lecsökkent a biztosnak és stabilnak mondható munkahelyek aránya. tendenciák hátterében, többek között, a szervezet pénzügyi, számbeli és idóbeli rugalmasságának biztosítása ál (Legge, 1998). Összességében átalakul a munkaadó és

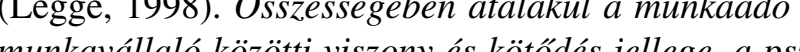
cholo

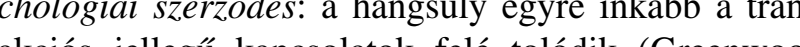
akciós jellegú kapcsolatok felé tolódik (Greenwoo 2007). Werhane és munkatársai (2004) egyenesen, „, tarsadalmi szerzódésrô" "beszélnek, amely - ellentétbe a „régi társadalmi szerzốéssel - már nem kínál stab állást, méltányos bért a munkavállalói teljesítményért és lojalitásért cserébe. Ez egyik oldalról tekinthetô a patenalista dominancia és kölcsönös függő́ség (örvendetes) végének, és az így kialakuló munkavállalói kapcsolato nevezhetjük érettnek, szabadnak, kihívásokkal telinek. Más értelmezésben azonban ez a változás inkább a személytelen, értelmetlen munkához, az elidegenedéshez vezet (Sennett, 1998). Osszességében ezeknek a változásoknnk nagy hás os lesz a szervezetekrés a bentotevékenykedố egyénekre, ezek kapcsolatára, illetve ennek etikai vonzatára.

Az etikai szempontok térnyerésében szerepet játszik az is, hogy a szervezet- és menedzsmentelméletekben is egyértelmúen erősödnek az etikai szempontokat integráló irányzatok. Ezek rámutatnak arra, hogy az etikailag problematikusnak vélt szervezeti dilemmák jelentôs részének köze van az EEM-tevékenységhez (p egyenlő bánásmód kérdése, drog- és alkoholproblémák kezelése, teljesítménymenedzsment és kompenzációs rendszer igazságossága). A pozitivista mainstream mellett eddig is jelenlevő kritikai ${ }^{4}$, posztmodern iskolák hangja is egyre hangosabb az utolsó húsz évben. Egyre inkább megkérdójelezik és kihívják az uralkodó Egyro is a modern vállalatokra jellemző komoly etikai feszinta moder val par feszültségekre, mint a munkaeró költségtényezóvé való lealacsonyodasa (commodification of labour) (Werhane al., 2004), a munkavallaló emberitoke-tényezókén való kezelése (human capital) (Martin - Woldring, 2001), a szervezetekben jelen lévó kizsákmányolás ès torz hatalmi viszonyok (Knights - Willmott, 1999). A modern gyakorlatok retorikája és a valóság közötti különbség nemcsak a mainstreamen kívüli elméleti és gyakorlati szakemberek véleménye: a vallott és képviselt értékek eltérése, a szervezeti integritás jelensége például komoly hangsúlyt kap a szervezeti szocializácó vagy a szervezeti kultúra irodalmában is.

A mainstream elméleten belül is felmerül a gondolat: az EEM azért harcolt, hogy a „,szolgálólány” szerep helyett stratégiai szerepet kapjon, és elismerjék legitim voltát (mind elméleti, mint gyakorlati szinten). Végül hatékony, menedzsmentorientált szakmai területté küzdötte fel magát, eközben azonban elvesztett valamit (Pasmora, 1999). Ebben a harcban elfelejtkezett a munkavállalók emberként való kezeléséról (emberi méltóság helyett már emberi cróforrásokról beszél, az embereket belső

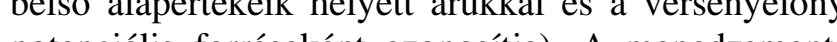
pons oldal érdeken

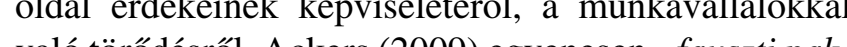
való törődésrớl. Ackers (2009) egyenesen „, fauszzi paktumrol " beszęl. az EEM szakértô lemondtak lelkükról a nagyobb befolyásért cserébe, és most lelketlen és személytelen módon, totálisan elkötelezettek a tulajdonosok és a menedzsment szolgálata mellett.

Egyes kutatók az EEM-funkció professzionalizálódásának, elkülönült szakmává válásának fontosságát hangsúlyozzák (Wiley, 1998; Martin - Woldring, 2001; Wooten, 2001). Az EEM elindult a szakmává válás útján, egyre inkább letisztultak a szakmai standardok, kialakult a szakmai képzés szerkezete és logi-

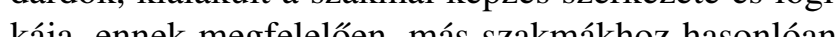

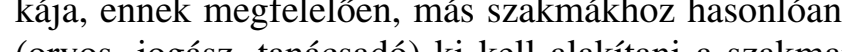
(orvos, jogász, tön kódexeket Ez pedig csak széles körú szakma disurzus nyomán, konszenzusra épülve készülhet el (Martin Woldring, 2001)

Végül az EEM-tevékenység a társadalom oldaláról is újszerú elvárásokkal szembesuil. Olyan kérdéskörök, mint az egyenlố banásmód, a diverzitás, a munkahely elvárt felelősségvállalása, a munkahelyi stressz, a munka és magánélet egyensúlya, egyre inkább a társadalmi, politikai viták kereszttüzébe kerülnek. Ezekre a kihívásokra a szervezeteknek, és ezen belül az EEM-nek valamiféle legitim választ kell találniuk.

\section{Mit jelenthet az etika, az etikus viselkedés}

\section{az emberieróforrás-menedzsmentben?}

Az etika meghatározására, az etikus viselkedés értelmezésére számos etikai keretrendszer létezik. Mint a gazdaságetika területén, úgy az EEM területére koncentráló etikai vizsgálódásokban is alapvetố fontossagú lesz majd az, hogy egyértelmú feltételezéseket fogalmazzunk meg az etikai keretrendszerról, illetve a szervezet céljáról, a vezetốk felelősségéról, a munkavállalók (vagy más érintettek) jogairól vagy felelôssé- 
géról. Greenwood (2002) úgy véli, hogy az EEM etika vizsgálatok sokszor adósok maradnak ennek az állásfoglalásnak az explicitté tételével.

Legalapvetóbb értelmezésként, az etika az EEM területén a munkavállaláshoz kötódó etikát (employmen ethics) jelentheti: Redman és Wilkinson (2009) ezt területet a gazdasági etika olyan részterületeként határozza meg, amely az általános morális alapelveket alkalmazza a munkavállalók kompenzációjával és a munkavégzés körülményeivel kapcsolatban. Mint ilyen, tekinthető olyan szakmai etikának, mint az orvosi vagy az ügyvédi etika, amelynek központja az orvosi vä az ü rek közötti kapcsola Êrtelmezen letre terjed ki, bár kotódik az általános etikához, illetve a gazdasagetika teruletéhez is, de megjelennek benne az EEM-terület speciális céljai, környezete, feladata problémái is (Pinnington et al., 2007), amelyek olya speciális fókuszt kívánnak, amelyet eddig a terület nem kapott meg.

Hagyományosan a munkaügyi kapcsolatok etika elemzése (1) a munkavállalói és munkaadói jogok és kötelezettségek, (2) az igazság és méltányosság gondolatköréhez, vagy (3) vallási irányzatokhoz kötö́ö̈t (Greenwood, 2002, 2007; Alford - Naughton, 2004). A munkavállalói és munkaadói jogok, kötelezettségek Az az alapvetó enberi szabadságjogokon túlmutatva tartamaznak a món es kötelességeket, és egyes elemeik beépültek a nemzetközi (pl. lLO), állami torvényekbe, jogszabályokba is. Crane és Matten (2007) kilenc munkavállalói jogot különböztet meg: (1) jog az egyenlő bánásmódra diszkriminációtól való mentességre, (2) jog a személyes szféra tiszteletben tartására, (3) jog a tisztességes eljárásokhoz (elốléptetés, elbocsátás, fegyelmi ügyek), (4) jog a kollektív tárgyaláshoz és fellépéshez, (5) jog részvételre, (6) jog a biztonságos és az egészséget nem károsító munkakörülményekhez, (7) jog a méltányos kompenzációra, (8) jog a lelkiismereti és szólásszabadsághoz, (9) jog a munkához.

Mindemellett (az akár törvényi szinten deklarált) munkavállalói jogok tiszteletben tartása a gyakorlatban egyáltalán nem egyértelmü a mai munkahelyeken, még az úgynevezett fejlett országokban sem (Werhane et al., 2004), pláne nem a harmadik világban (Greenwood, 2007). De kérdéseket vet fel akár Magyarországon is. A munkavállalók mögött sokszor nem áll olyan erô, amely ki tudná kényszeríteni ezeknek a jogoknak biztositását (egyes gondolkodók szerint ezért kérdéses, hogy ezek a valóságban ténylegesen léteznek-e, lás például Koehn, 2002). A jogokra alapuló vizsgálatok azzal a problémával is szembenéznek, hogy az egyes jo- gok értelmezése nagyon kontextusfüggó lehet. Gondoljunk például arra, hogy a biztonságos és egészséget nem károsító munkahely mennyire más jelentéssel bírhat egy afrikai bányában, az USA-ban, vagy akár Magyarországon egy hasonló vállalatnál. Elméleti jellegû́ kritika, hogy az alapvetó munkavállalói jogok egymással is ellentmondásba kerülhetnek (pl. egyenló bánásmód és a méltányos kompenzáció), illetve minőségi értelemben túlságosan szúkre szabottak (nem mindegy például, hogy az egyénnek milyen jellegú munkához van joga) Az alapvetó jogokat kiteriesztve Bowie (1998) kialaḱ́tja az ételmes muḱ́noz való jog fog (1998) kialafogalmát (amely (1) a tekinthetó egyetemesen elfogadottnak) (1) a munkahely szabadon választott, (2) a munkavállaló onallósággal bír, (3) lehetôsége van fejlódni, (4) megélhetest biztosító bert kap, (5) a munkahely a munkavallalo morális fejlódését biztosítja, (6) a munkahely nem befolyásolja paternalista módon az egyén életét, az egyéni boldogság elérésének módját. Kérdéses azonban, hogy például egy mai magyar vállalat a gyakorlatban hogyan és mire tudná lefordítani például a morális fejlődés biztosítását (Greenwood, 2007).

Az igazságossághoz, méltányossághoz kötődố vizsgálatok gyökerei szintén messzire nyúlnak: azok a kérdések hogyan kell méltányosan és igazságosan kezelni a munkavállalókat, mi az igazságos és méltányos bér mit vá havt el adott bérét a munkán, mit és tén tén régóta foglalkoztatják az elméleti és gyakorlati szakembereket. A vizsgalatokat megalapozó szervezeti igazságosság fogalma három, egyaránt fontos igazságosságfogalmat takar (Greenberg, 1993): (1) a disztributív igazságosság fogalma alatt azt az észlelést értjük, hogy annyi és olyan jutalmat kaptunk-e, amit megerdemeltün, (2) a procedurâlis igazság fogalma a jutalom elosztási folyamatának igazságosságára, fair voltára koncentrál, illetve (3) az interperszonális igazságosság a folyamatokban észlelt bánásmód, az emberi méltóság tiszteletben tartására vonatkozik (Greenwood, 2005). Az igazśágosśá szempontjai az egész EEM múködéśben, iletve az egyes rendaz az a rendsze-

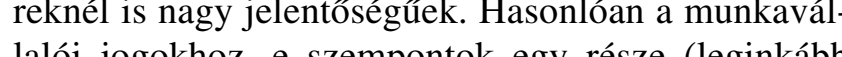
lalô jogokhoz, e szenpontok egy része (leginkább a procedurális igazság szempontjai) beépült a jogszabályokba (pl. az egyenló banásmód elve). Azonban például az interperszonális igazságosság szempontjaival ez nehezen elképzelhetô, másrészt hiába egyre részletesebb a munka területéhez kapcsolódo törvényi szabályozás, ha párhuzamosan a nagyvállalatok hatalma és befolyása is nó (Greenwood, 2007). A számos, igazságosságra koncentráló vizsgálat közül Weaver és Trevino (2001) a szervezeti igazságosság perspektívájából vizsgálták az EEM szerepét az etikai programok végrehajtásában

Az egyes vallások tanításaira épülő analíziseknek szintén nagy hagyománya van: Stackhouse és munkatársai (1995) az ókori héber tradícióktól kezdve számos keleti és nyugati vallás tanítását alkalmazzák üzleti, valamint ezen belül és ezekkel integrált módon az EEM-gyakorlatokra. Johnson (1995) saját gyakorlati tapasztalataira épülve javasolja a munkavállalói kapcsolat keresztény alapokra való helyezését, a szervezet „egymást kölcsönösen támogató és kiegészitó közösség"'-ként való értelmezését, a munkavégzési rendszerek radikális átalakítását az emberi méltóság és a szeretet paradigmájára építve. Cortright és ság és a szeretet paradigmajára építve. Cortright és tásaira építve - EEM-rendszereket (képzés, fejlesztés, tásaira építve - EEM-rendszereket (képzés, fejlesztés, kompenzáció, munkakörtervezés) vesznek górcsó alá, és konkrét modelleket alkotnak, mint a teljes emberi
fejlódés modellje (Alford - Naughton, 2004), a humafejlódés modellje (Alford - Naughton, 2004), a humanisztikus munkatervezés (Murphy - Pyke, 2002). Magyar példaként Hegedús (2010) a Biblia alapján határozza meg a legfontosabb EEM-alapelveket. Ezekre az analízisekre egyszerre jellemzó az igény az egész modern vállalat alapértékeinek megváltoztatására, illetve az egyes gyakorlatokban a vallásos - nemcsak keresztény, hanem hindu, muszlim, konfíciuszi stb. értékrendeknek a megjelenítésére.

Az utolsó húsz év vizsgálódásait a jogokra, az igazságosságra és a vallási alapelvekre épülő analízisek mellett a "tradicionális” etikai nézópontok (utilitarista, erényetikai, kanti kötelezettségetikai, gondoskodás alapún) jellemezték A bevezetóben idézett Karkodás al pư) jellemezték. A bevezetôben idézett Karen Legge (1996, 1998) nagy hatású elenzésében négy iskola, azutilitarista, Rawls rendszere, illetve a kanti és az arisztotelészi erényetika-alapú feltevéseinek fényében vizsgája a puha és kemény EEM-szemléletet, és hangsúlyozza, hogy az EEM elemzése és értékelése nagyban melyik etikai keretrendszert alkalmazták.

hogy melyik etikai keretrendszert alkalmazták.

Összefoglalóan ezekben az elméleti és gyakorlati vizsgálatokban az etika és az EEM összekapcsolására többféle logikát követtek a szerzók:

1. Az adott etikai iskolá(k)ból kiindulva megvizsgálták, hogy ezek külön-külön, illetve együtt mennyire és hogyan alkalmazhatók az EEM elméletére és gyakorlatára (Schumann, 2001; Koehn, 2002).

2. Egy vagy több etikai keretrendszer alapján értekelték az EEM egészét vagy valamely aspektusát, az elméleti alapfeltevéseket (pl. kemény vagy puha EEM) vagy a szervezet gyakorlatát, a szervezeti kultúrát (Legge, 1998; Weaver - Trevino,
2001: Kujala - Pietilainen, 2007; Ackers, 2009; Montemayor, 2006).

3. Megkísérelték azonosítani és besorolni, hogy a szervezetek vagy a szervezeti szereplók tetteiben, magatartásában, retorikájában, dokumentumaiban milyen etikai alapelv(ek) érvényesülnek, vagy nem érvényesülnek (Fisher, 1999; O'Higgins Kelleher, 2005; Wasieleski - Weber, 2009).

4. Azonosították és csoportosították az érintettek által etikailag problémásnak vélt, az EEMevékenységhez kötődô eseteket valamely etiai keretrendszerben értelmezve (Wiley, 1998; Wooten, 2001)

Az elemzéseket nehezíti, hogy - amint Greenwood (2007) is rámutat - a szervezeti helyzetek sokszor nagyon komplexek, számos érintett jogai, érdekei, kötelezettségei szerepet játszanak bennük, és e jogok, érdekek, értéek egymással feszïltségben vannak jelen. Eme épiilve e.m is) egy lehetséges út lehet, ha elfogadó és sokszínú módon több nézőpont, keretrendszer egyszerre jelenik neg. Ebben a (lehetséges) sokféleségben Greenwood ennek pluralista természetében rejlő lehetôségeket.

Milyen szinten értelmezhetó az etikai vizsgálódás az emberieróforrás-menedzsmentben?

Az 1990-es években jellemzően két szinten vizsgálták az EEM-tevékenységhez kötődő etikusságot: a makroszintú elemzésekben a kanti és az utilitartista etikai elméleteket alkalmazták az EEM egészére, mikroszinten pedig az igazságosság- és méltányosságelméleteket, a munkavállalói jogok szempontjait alkalmazták meghatározott EEM-gyakorlatokra, -helyzetekre (Greenwood, 2002; Greenwood - de Cieri, 2007). Martin és Woldring (2001) három lehetséges elemzesi szintet haározott meg: (1) az EEM alrendszereinek etikai szempontú vizsgálata, (2) az egész EEM-tevékenység etikai aspektusainak elemzése, és (3) az EEM szerepének vizsgálata a vállalati szintú etikai kérdésekben.

A szintek természetesen - mind elméleti, mind gyakorlati értelemben - szervesen kötődnek egymáshoz, tehát a csoportosítás mesterséges, és helyenként erôltetett is, pl. az egyes EEM-szerepek etikussága, és ennek egyéni észlelése, a kapcsolódó egyéni, morális viselkedés szoros kapcsolatban van egymással. A következókben a három szintet kibővítve, négy lehetséges szintet tekintek át röviden: minden szinten bemutatok egy vagy több, erre a szintre koncentráló, meghatározó munkát (1. táblázat) 
Az etikai vizsqálódások szintje, jellemzố kérdések és kapcsolódó munkák az EEM-ben

\begin{tabular}{|c|c|c|}
\hline & Jellemzố kérdés, fókusz & Kapcsolódó munka \\
\hline Makro- (rendszer) szint & $\begin{array}{l}\text { - A modern gazdasági környezet és rendszer, a vállalat } \\
\text { alapfeltevéseinek, múködésének etikai szempontok mentén } \\
\text { való elemzése. } \\
\text { - Az EEM mint tevékenyység különbözó felfogásainak (pl. puha } \\
\text { és kemény EEM) vizsgálata. }\end{array}$ & $\begin{array}{l}\text { Legge (1998) } \\
\text { Bauman (1993) } \\
\text { Ackers (2009) } \\
\text { Guest (2007) }\end{array}$ \\
\hline $\begin{array}{l}\text { Mezo- (vállalat, szervezet) } \\
\text { szintú elemzés }\end{array}$ & $\begin{array}{l}\text { - A váillalat felelolós viselkedéséhez, etikusságához való } \\
\text { hozzájárulás, az ebben való részvétel és az ehhez kapcsolódó } \\
\text { felelốsség. } \\
\text { - A vállalaton belüli etikai bajnok szerepe, illetve az etikus } \\
\text { szervezeti kultúra, etikus kommunikáció, etikus vezetés } \\
\text { kialakitásában való részvételre koncentráló vizssgálatok. }\end{array}$ & $\begin{array}{l}\text { Lepak és Colakoglu (2006) } \\
\text { Orlitzky és Swanson (2006) }\end{array}$ \\
\hline $\begin{array}{l}\text { EEM-szervezet, -funkció } \\
\text { szintje }\end{array}$ & 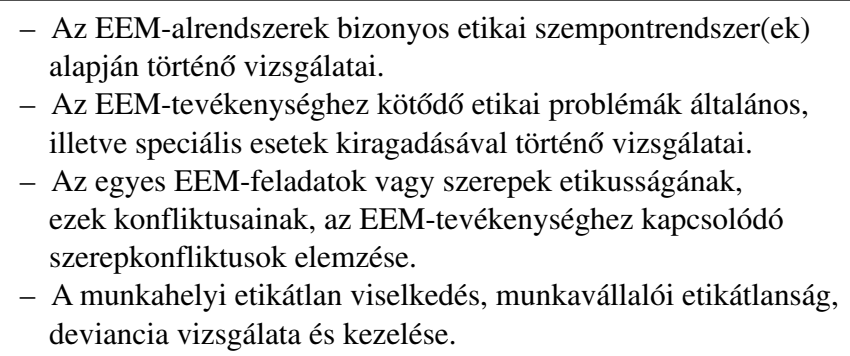 & $\begin{array}{l}\text { Mathis és Jackson (2006) } \\
\text { Alford és Naughton (2004) } \\
\text { Murphy és Pyke (2002) } \\
\text { Wooten (2001) } \\
\text { Wiley (1998) } \\
\text { Ulrichés Beatty (2001) } \\
\text { Cardy és Selvarajan (2006) } \\
\text { Schumann (2001) }\end{array}$ \\
\hline Mikroszint: egyéni szint & $\begin{array}{l}\text { - Az EEM-tevékenysséghez és szerephez kötódó egyéni morális } \\
\text { döntéshozatal, az egyéni észlelések és értelmezések vizsgálatai. }\end{array}$ & $\begin{array}{l}\text { Wooten (2001) } \\
\text { Dachler és Enderle (1989) }\end{array}$ \\
\hline
\end{tabular}

\section{A vállalat egészének etikussága}

az EEM-funkció etikussága A marxista gondolatkörben a kapitalista szervezet egy-
értelmúen etikátlan, az EEM egyértelmúen a kizsákmá-

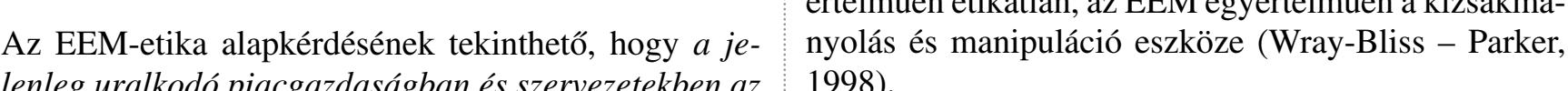
lenleg uralkodó piacgazdaságban és szervezetekben az 1998).

EEM bármilyen elmélete és gyakorlata lehet-e egyáltalán etikus? Legge (1998) értelmezésében ez a kérdés indukál még két következő felvetést: elóször, mit is értünk etikusságon? Másodszor - ha az etikus EEM nem csak utópikus elképzelés, és létezhet etikus EEM, akkor -, milyen jellemzókkel bírhat ez a valóságban? Amennyiben a kapitalista berendezkedést etikusnak tekintjük (vagy legalábbis látjuk a lehetőséget az etikus vállalati viselkedésre e berendezkedés keretein belïl), akkor erre épülve ez az EEM esetében is lehetséges. Az akor azonban kéclls, hogy egy alapvetôen etikátlan gazdasági rendben lehetséges-e etikus EEM-tevékenységet
végezni, a munkavállalókat etikus módon kezelni (bármilyen etikai keretrendszer alapján)?

A kérdésre adott válaszok számosak. Marx (és köA kérdésre adott válaszok számosak. Marx (és követóinek) argumentuma alapján a kapitalista vállalatokképességeik és kreativitásuk, szabadságuk korlátok nélküli gyakorlásától. Az embereket a profit eléréséne érdekében dehumanizálják, a tárgyakhoz hasonlóan hasznositják (eltarroyiasulnak), kizariảk ôket a döntés- hozatalból, amely a munka elidegenedéséhez vezet. Bauman (1993) véleménye szerint a modern szervezetekben az egyének viselkedése szigorú szabályok közé szorított, és számos eszközzel kontrollált (például bürokratikus és kulturális módszerekkel), hiszen a vállalati cél, a nyereségesség elérése érdekében szükséges a kollektív cselekvés. A vállalati kontroll és nyomás, helyenként az uniformitás kiszorítja és leépiti az egyéni etikai felelósségvállalást és morális érzékenységet. A szervezet azt várja el az alkalmazottaktól, hogy azt tegyék, amit a főnök mond, nem pedig azt, amit jónak, helyesnek ́́reznek sajútérćkrendijk és múcćjik szerint (Jackall, 1988). Összessépéb a vallatu intézé intézményesult formaban erodalja az egyeni lelkiismeretet és moralitast - hogyan is lehe ez a képzodmény etikus (Bauman, 1993)? McIntyre (1997) úgy véli, a mealapvetốen a munkavállalók manipulálásán alapul. Ráadásul a szervezetben való nem kiegyensúlyozott, fragmentált fejlődés következtében az egyének lényegi identitása sérül, és korrodálódik a morális karakter (Wray-Bliss, 2007: p. 520.; Legge, 2005: p. 36.). nedzsmenttevékenység maga nem lehet etikus, hiszen

VEZETÉSTUDOMÁNY

Legge (1998) elemzésében Adam Smith eredeti elképzelése a decentralizált és szabad piacról, a versenyról, a kereslet-kínálat önszabályozásáról a saját korába etikusabbnak volt tekinthetô, mint a korabeli merkantilista gazdasági berendezkedés. Az utilitarista kererendszerben a smith-i kapitalizmus az egyéni szabadság és a termelési hatékonyság kombinációja, amelybe minden egyén - racionális önérdekét követve - hoz zájárul a társadalom jólétéhez. Azonban már Smith is felhívta a figyelmet arra a veszélyre, amikor a gazd sági erố kevés szerepló kezében összpontosul, és ennek sági eró kevés szerepló kezében osszpontosul, és ennek következtében torzul a piac. Jelenleg egyértelmúen ez a helyzet - például a globális vállalatok komoly gazdasági-politikai hatalommal bírnak. Ráadásul kérdéses tétele is. Fairnek nevezhetünk egy tranzakciót, ha a fetétele is. Fairnek nevezhetünk egy tranzakciót, ha a felek szabadon (kényszer nélkül) dönthetnek, és azono informáltsági szinten vannak. De a mai vállalatokba vajon mennyiben tekinthetố a munkaadó és munkaválaló közötti viszony fairnek? Milyen valós választási lehetôségei vannak egyáltalán az egyénnek a munkába való belépéskor (ha az alternatíva a munkanélküliség), hogyan utasíthatja vissza egy munkavállaló a kötelező túlórát, az etikátlan fónöki utasítást (ha az alternatíva az elbocsátás)? Hogyan lehetne az egyén azonos informáltsá́gi szinten, amikor a vállalatok kontrollálj informáltsági szinten, amikor a valllalatok kontrollálj a médiát? Ezek alapján komoly dilemma, hogy akár az len múködésében a kapitalista vállalatot?

\section{Az EEM mint a tevékenység alapfeltevéseinek} etikussága

Számos elméleti és gyakorlati munka vizsgálja etik szempontok alapján az alapvetó EEM-modellek (mint a puha és kemény EEM, vagy a stratégiai EEM) alapvetéseit, illetve múködését. Legge (1998) elemzésében a kemény és puha EEM-modellre fókuszál: magyarázatában egyedül az utilitarista szempontrendszer az, amelyben elképzelhetố a kemény EEM-modell etikussága, amennyiben biztosítja a szervezeti túlélést, és ezáltal a nagyobb társadalmi hasznossághoz vezet. A kanti keretrendszer szempontjai alapján a kemény modell határozottan etikátlan, hiszen a munkavállalókat eszközként, nem pedig célként kezeli. Az erényetikat eszközként, nem pedig célként kezeli. Az erényetikában a kemény EEM szintén nem tekinthető etikusnak, hiszen a személyiség kiegyensúlyozott fejlődése
távolról sem biztosított. A puha EEM analízise már kedvezóbb képet mutat(hatna): az erényetika alapfeltevéseinek megfelelhetne, azonban, mint Legge rámutat, az egyénre eróltetett munkahelyi szerepek alapvetóe eltorzíthatják a valós erényeket, a munkaalkoholis életmód megakadályozza a magánéletben, a családban aló kiteljesedést és a harmóniát. A puha EEM a kant róbán is átmehetne, ám többek által felvetett kérdés ogy a retorika (a munkavállalókra való fókuszálás) és valóság (ugyanók manipulálása) ezekben a szervezerekben mennyire tér el egymástól.

Guest (2007) elemzésében az EEM-modellekhez kapcsolódóan úgy véli, hogy a stratégiai EEM-rendszer és -szervezet, amely elvileg a munkavállalók menedzselésével foglalkozik, valójában (1) ignorálja óket, figyelmen kívül hagyva érdekeiket, (2) sőt valójában EEM a kizś́kmányolás f" eszközévé válik. Ḿ́ga lóbbi jelóg különösen jellemzố a kemín. Míg az a

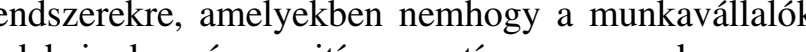
erdekei, de még pozitiv, negatív vagy semleges reciói sem jelennek meg (egyfajta fekete dobozkén vagy robotkent ábrázolja ốket), addig a puha EEMendszerekben - Legge analízisének megfelelóen - az EEM a manipuláció központi eszközévé válhat.

Ackers (2009) a megtévesztés (etikátlanság) három alapvetó formáját értelmezi az EEM-tevékenység alapfeltevéseiben. Az (1) aranybika szemléletmód minden emberi értéket alárendel az üzleti, gazdasági megfontolásoknak. Az emberi lényt újradefiniálja a maga komplex anyagi, társas, spirituális szükségleteivel együtt, és személytelen gazdasági kategórián (eruforńśá) écozza táco tározza és alakíja az egyéni motivációkat és szükségleteket, minden EEM-dôntesnek (amelyet üzleti döntésnek tekintünk) van a költsége és a megtérülése. Az aranybika szemléletmódot követô EEM eladta lelkét, és most ,az aranybika, a hamis értékek oltárán áldoik" (Ackers, 2009: p. 463.)

A (2) felvilágosult önérdekkövetés szemléletmód képviselói azt állítják, mivel a vállalatoknak hosszú távon érdeke, hogy a munkavállalókkal (és egyéb érintettekkel) bizalmon alapuló, belsố integritást tükrözố kapcsolatokat alakítsanak ki, erre épülve érdekükben all az ezt megalapozó etikus viselkedés is. Ebben a Keretrendszerben a felvilágosult vállalat, sajét önér-

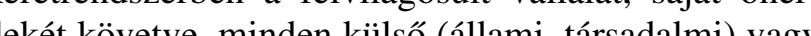

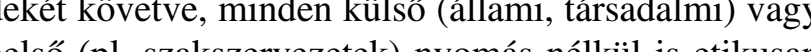

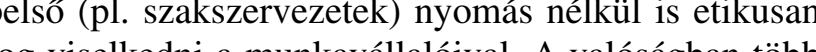
g viselkedni a musara több szempontból is problemákat rejt ez a nézőpont. Egyik tilu etikus viselkedés és a vállalati sikeresség kapcsolatának vizsgálata ellentmondásos eredményeket produkáló, kevéssé egzakt terület. Másik oldalról a vállalatok sokszor alárendelik a valódi, hosszú távú célokat a rövid távú érdekeknek (például a vállalati retorikában a hosszú távú fenntarthatóságot a rövid távú túlélésnek), ráadásul a mobil, általában tranzakciós alapon szerző-

\section{VEZETÉSTUDOMÁNY}


dô vállalatvezetés számára a hosszú táv fogalma nem is feltétlenül releváns fogalom. Erre épülve a felvilágosult önérdeken alapuló etikusság meglehetősen bizonytalannak, esetlegesnek tekinthetô.

A (3) boldog család szemléletmód követối úgy érzik, hogy a vállalat és a munkavállalók kapcsolata egy boldog családhoz hasonló, amelyet a szakszervezetek és az állam csak elrontana. Ez a szemlélet a paternalizmus alapelvein nyugszik, de nélkülözi annak érzelmi jellegú kötôdéseit (pl. már nem családok egymást követố generációi dolgoznak egy vállalatnál, életük végéig), alapvetően kalkulatív bázison nyugszik, és sekszêg), alapvetốn kalkutu bazison nugsik, es sokszor alapvetóen képmutatô (pl. egyes munkavallalói csoportokra). Ami megmarad, az a mu Ackers (2009) végül kiemeli, hogy különbséget kell tenni a munkavállalơhoz köhetó etikusság, mint $a$ társadalom felé irányuló kirakat és maszk, a rövid táva haszonmaximalizálásra és önérdekkövetésre épülő gazdasági tevékenységet legitimáló szemlélet és gyakorlat, illetve a munkavállalók iránti valódi felelósségérzeten nyugvó etikai szerep között, amelyben a partnerség, a lojalitás és a szervezet morális közegként való felfogása a valódi cél.

\section{Az EEM hozzájárulása a vállalat felelós \\ viselkedéséhez, etikusságáho}

A vizsgálatok másik csoportja a vállalati etikusságho való hozzájárulás, és az ebben való részvétel, a vállalaton belüli etikai bajnok szerep (Greenwood, 2007), illetve az etikus szervezeti kultúra és kommunikáció, etiku vezetés kialakításában való részvételre koncentrál. Ezeknek egyik irányát azon alapfeltevés determinálja, hogy az egyéni etikusságot befolyásoló kontextuális tényezôk alakításában (mint a javadalmazási rendszer, a szervezeti kultúra, a munkahelyi szerepek formális leírásai) az EEM-területnek nagy szerepe van (Crane - Matten, 2007), tehát az EEM hatókörébe tartozó tényezók a vállalat összetikusságát is nagyban fogják befolyásolni.

Orlitzy és Swanson (2006) amellett érvel, hogy az EEM-tevékenység alapvetôen elősegítheti a vállal felelős viselkedéśt azáltal, hogy az EEM-rendzerek múködésében (különösen a kompenzáció, teljesítményértékelés, kiválasztás, képzés-fejlesztés rendszerében) az elméletben és a gyakorlatban következetese a felelós szervezeti viselkedéshez kapcsolódó értékeket képvisel, azaz értékhangolt (value attuned), és így $\mathrm{k}$ alakítja, fejleszti és újratermeli a felelős viselkedést támogató szervezeti kultúrát. A kiválasztás területén ez például azt jelentheti, hogy az egyének kognitív morális fejlettsége, illetve a morális érzékenység és morális re- ceptivitás (moral receptivity) fontos kiválasztási szempontok (és persze a képzésben is megjelennek), illetve a valllalat valóban a munkaeró diverzitására törekszik, feltételezve, hogy a sokszínú munkaeró fogékonyságában is sokszínúbb, és így nagyobb biztonsággal érzékeli a különböző érintettek értékelvárásait. A szerzók feltételezése szerint a kifejezetten homogén közösségek hajlamosak lehetnek bizonyos alternatívák kizárására, kollektív, morális racionalizálásra. A teljesítményértékelés céljai között a gazdasági célok mellett társadalmi, ökológiai, morális célok is szerepelnek, amelyeket a szervezet közö̈s cón is szeg (esetleg kiilsó érinet a en kulsô érintettek is is megjelennek. Kétséges persze, hogy egy alapvetően individualista, versenyző szervezeti kultúrában kitúzhetơk és elérhetơk-e olyan társadalmi, morális célok, amelyek eléréséhez bizalomra, együttmúködésre lenne szükség. Ebben a logikában az értekre hangolás egyben a szervezeten belüli morális integritást is kell, hogy jelentse. Az értékre hangolt szervezeti kultúra az egyéni és szervezeti miópia ellenpontjának tekinthetó, amely általában a személyes értékek tagadását, az érintettek elvárási értékoldalának figyelmen kívül hagyását, és ezáltal a gazdasági célokra való kizárólagos koncentrálást jelenti (Orlitzky - Swanson, 2006).

A vállalat számos érintett érdekei, igényei, szükségletei között egyensúlyoz: abban, hogy ezek közül ne csak a domináns érdekek teljesüljenek, és a szervezet felelôsen, etikusan viselkedjen, fontos szerepe lehet az érintettelméletre alapuló stratégiai EEM-szemléletnek. Lepak és Colakoglu (2006) elemzésükben példaképpen bemutatják a Costco nevú szupermarketláncot (a Wal-Marttal kontrasztban), amely árversenyző stratégiát követ a piacon, de munkavállalóinak a konkurenciánál 42\%-kal magasabb bért fizet (egyéb juttatások mellett), és pénzügyi teljesítménye mégis elfogadható. A szerzốk úgy vélik, hogyha vállalati életciklusokban gondolkodunk, kialakítható az érintetti igények figyelembevételének egyfajta ritmusa, amelyben bizonyos vállalati szakaszokban más-más érintettek kerïlnek a vállalati szakaszokban más-más érintettek kerülnek a rókuszba (pl. korai szakaszban a befektetók, érett szakaszban a munkavállalók). Az etikusan múkódó EEM-
rendszereknek alapvetően ezt a stratégiai látásmódot kell támogatniuk.

\section{Az EEM-alrendszerek vizsgálata, etikai} problémák és etikailag kérdéses esetek

Az EEM-tevékenységhez kötődố etikai problémák, etilönbözó megoldásokkal találkozhatunk. Egyes szerzốk a vállalati gyakorlatban található speciális, összetett ese- tekre koncentrálnak, amelyek az igazságosság, a megbízhatóság és a társadalmi felelősségvállalás kérdéseive hozhatók kapcsolatba, és különösen nehéz óket megodani: pl. olyan munkavállalók kezelése, akik már régó a vállalat alkalmazásában állnak, de a szervezeti változások miatt elvesztették munkájukat, vagy a dohányzási tilalom a munkahelyen (Mathis - Jackson, 2006) Mások általánosan megfogalmazott etikai problémaköröket vizsgálnak, mint a diszkrimináció, a pszichológiai tesztek alkalmazása, a szakszervezeti tevékenység blokkolása a munkavégzési rendszerek kilakútáso, a

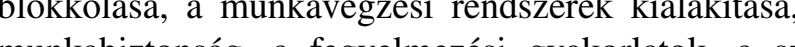
munkabiztonsá, a fegyelmezsi gyakorlatok, a személyiségi jogok, a kiszervezés és elbocsátás, az adatok bizalmas kezelése (Wooten, 2001). Az elemzésekb egyaránt megjelenik az adott terület (az EEM-rendszer: pl. kiválasztás, vagy a problématerület: pl. favorizmu rendszerszintú elemzése, és a rendszer múködése nyomán felmerüló (EEM-tevékenységhez kötődó) elemzés, illetve a munkavállalók (vezetók, beosztottak) etikátlan viselkedésének vizsgálata az adott helyzetben.

További csoportot képezhetnek azok a munkák, amelyek az etikailag kérdéses esetek listázására, kategorizálására törekednek: Wooten (2001) a gyakorlatra építve kísérletet tett az etikai dilemmák valóban alapos kategorizálására Ot általános etikai problémakategótiat értelmezett a nyolc (alapvetô) EEM-rendszerben, át êter negyven potencialis etikátlan viselkedést, gyakorlat azonositot, anclyet az EEM elkövethet. Ezek az etikai problénakategoiák (1) a gévesztés és összejâtszás, (2) az adatok nem rendeltetésszerú használata, (3) a manipuláció és kényszerítés, (4) az értékek és célok konfliktusai, (5) a szakmai felszínesség. Modelljébe hangsúlyozza az egyéni, szervezeti és szakmai etiku ság, illetve az elvárások konfliktusát, és ennek hatását az EEM-tevékenységre (Wooten, 2001)

Izgalmas vonulat a kutatásokban az észlelés (és az észlelési torzítások) nagy szerepe az EEM-tevékenysé etikusságával, illetve az etikus magatartással kapcsolatban (ehhez kapcsolódóan ismét a kommunikáció fontossága és az etikus viselkedés fejlesztésének lehefons (2006) ku-

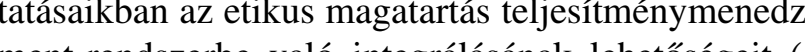
ment-rendszerbe való integrálásának lehetôségeit (és nehézségét) elenzik, illetve az egyéni teljesítmény és az etikátlan munkahelyi viselkedés észlelését vizsgá ják. Meglepó eredményük, hogy az etikátlan viselkedés észlelése negatív kapcsolatban van a teljesítménnye: minél „sikeresebb” valaki, annál kevésbé észlelté (vagy kommunikálták) az etikátlan magatartást. Ezeket hat dimenzióban értelmezték: megvesztegetés, csalás hamisitás, hamis riportok készítése, munkatársak etikátlan kezelése és vállalati erơforrások pazarlása. Wiley
(1998) kutatásában az EEM-tevékenységhez köthetố etikátlan jelenségek komolyságát és gyakoriságát, illetve a nem, a hierarchikus pozíció, a vállalati nagyság és az iparág ezek észlelésére gyakorolt hatását vizsgálta. Az EEM-területek kozött az áramlás, a kompenzáció, illetve a munkavédelem és az egészség területén észleltek leggyakrabban etikátlan eseteket; az esetek súlyosságánál ugyanezen területek, csak más sorrendben jelennek meg (az etikailag legsúlyosabb eseteket a munkavédelem és az egészség területén találták).

Dachler és Enderle (1989) rámutat arra, hogy az EEM-funkció képviselóinek alapfeltevései, értékei alapjaiban határozzák meg azt, hogy egyáltalán észlelik-e az etikai kérdéseket, azaz a morális érzékenység jelentőségét hangsúlyozzák.

\section{Az EEM-szerepek}

E vizsgálatok egyik csoportjába az EEM szakmai, szervezeti és egyéb szerepek közötti konfliktusok etikai szempontú elemzései sorolhatók. Wooten (2001) értelmezésében az EEM-szerepben az egyén folyamatosan egyensúlyoz személyes, szakmai és szervezeti etikai alapelvek és elvárások között. Akkor beszélhetünk etikai dilemmáról, ha az EEM-szakétő feladatának elvégzése közben olyan különbözô elvárásokkal szembesïl amelyek során a személyes, a szakmai és a szembesul, cécer tek en, alapelvek, hiedelmek, elvárások, szükségletek 165.) E p. 165.). Etikátlan viselkedéssól akkor beszélhetünk, ha egy EEM-funkcióhoz köthetó döntés, vagy ennek eredményeképpen kialakuló magatartás egyéni vagy szervezeti szinten kárt, sérülést okoz

Wiley (1998) az etikai problémák megoldása során azonosít EEM-szerepeket. A nyolc szerep közül (egyegy helyzetben több szerepet is azonosítottak a megkérdezettek) az esetek 94\%-ában „nyomozó” szerepben észlelték magukat, amelyben etikai szempontból nem egyértelmú helyzeteket próbáltak tisztázni. 92\%-ban monitoring" feladatkörben (amikor is a törvényeknek, illetve bes" szál

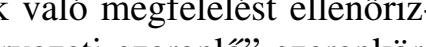
(en) ben (amikor a szeervezet valamely döntését, vagy magát a szervezetet kellett megvedeni valamely külso szereplótôl). A szerzók a többi szerep (tanácsadó, képző-fejleszto, munkavallaló érdekképviseló, megkérdójelezó, mintaadó) említési arányát nem részletezik - de az sokat elárul, hogy egyértelmúen a (külső-belsô) kontroll típusú szerepeket észlelték gyakorinak.

Meglepó módon kevés vizsgálat irányul a klasszikus EEM-szerepek etikusságának elemzésére. Mind Storey (1997), mind Ulrich (1997) szerepmátrixa kap- 
csán megjelenik az EEM-szerep sokszínúsége, amely abból adódik, hogy sok különbözó feladat, kötelezettség és felelősség van jelen, amelyek sokszor egymáss (extrém esetben adott szerep saját magával is) ellentétesek. Ugyanakkor kimondottan etikai szempontok egyik szerzônél sem jelennek meg. Direkt módon megjelenik azonban az etikusság Ulrich és Beatty (2001) következó csoportosításában, amelyben az EEM szerepeit már nem partneri, hanem játékosi szerepekként értelmezik. Ezek közül különösen izgalmas a „lelkiismeret" szerep: ezt a szerző́k olyan belsố bírói szerepkén (conscience referee) értelmezik, amely biztosítja, hogy a szervezet és tagjai a szabályoknak megfelelóen, ezek a szervezet és tagjai a szabályoknak megfelelóen, ezek betartásával tevékenykednek. Ez azért fontos - a szer-

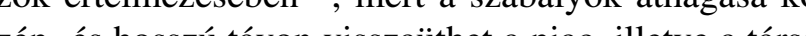
zép- és hosszú távon visszaüthet a piac, illetve a társdalom megitélésében, vagy akár csökkentheti a vállal vonzerejét a munkavállalók szemében (az érvelésbe kissé keveredik a jogkövetés és az etikusság fogalm illetve a szerzốk egyértelmúen a megtérülố jellegú etikusságra építenek). A „lelkiismeret” szerep nem hálas (és nem vágyott), az ốszinte és az igazságért küzdó, a gyanús és egyértelmúen problémás esetekre, gyakorlatokra rámutató játékos a pálya szélére kerülhet, vagy le is cserélhetik. A jelen gyakorlatban - vélik a szerzók - az EEM sokszor az etikai problémákkal az esetleges botrány (szexuális zaklatás, beszámolók me eseleges botrány ( sa, környezetszennyezés) kirobbanása után szembes (mint tuzzoltó vagy a fontos lenne az EEM stratégiai és proaktív szerepe etikai iránytúként való funkcionálása

Caldwell (2003) kutatásában Egyesült Királyságbeli mintán vizsgálta Storey (1992) és Ulrich (1997) egymással részben átfedő szerepeit: elemzésében arı mutat rá, hogy a szerepek mindegyike belsó ellentmondások sokaságát hordozza (mindegyik egy-egy külö „Pandora szelencéjének” tekinthetô), ráadásul Storey szerepei a valóságban nagy részben jelentôsen átfedik egymást (pl. a tanácsadó és a változási ügynök szerep). Osszességében az Ulrich-szerepek jobban tükrözik megváltozott szervezeti viszonyokat, de maga a modell - túlságosan leegyszerúsítve a valóságot - irreális célokat tûz ki: figyelmen kívül hagyja az új szerepekben is jelen lévố régi konfliktusokat és a múltbeli EEMszerepek árnyait (pl. reaktív magatartás), illetve az EEM-tevékenységet egységként kezelve nem foglalkozik a vállalaton belüli különbözó hatalmi viszonyokk és az érdekek pluralizmusával.

Caldwell négy területen értelmezett szerepkonfliktusokat az EEM-tevékenységben: (1) A szerepek kozötti konfliktusok (amikor az egyes szerepekhez tartozó feladatok egymással ellentétes tetteket igényelnek, együttesen túl sok van belólük, és egyik csak a másik rovására hajtható végre). (2) A szerepen belüli konfliktusok (egyazon szerepen belül jelentkeznek ellentétes elvárások vagy nem egyértelmúek a teljesítménykritériumok). (3) Az érték-szerep konfliktus, amikor egy konkrét szerepben az egyéni vagy a szakmai értékek ellentétesek a szereppel vagy a feladattal, illetve (4) régi-új szerep konfliktus, amikor valamelyik új, elvárt szerep (pl. változási ügynök) kerül konfliktusba valamelyik régi szereppel (Caldwell, 2003).

Az EEM-szerepekhez köthetố emblematikus kutatás Magyarorsź́gon a 2004-ben útnak indított HR Tükör kutatás (Bokor et al. 2005), amelynek elsó fáziśt azóta már hár

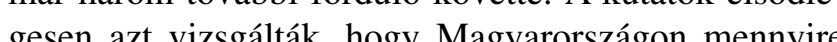
tekinthé az EFM-munkáloz azét az EeM-nen mennyiben különbözőek, milyen kompetenciákat tartanak a legfontosabbnak (Bokor et al., 2005). A kutatás számos izgalmas eredménye közül most csak azokat a gondolatokat emelem ki, amelyek a szerepek ellentmondásait és etikai aspektusait illetốen érdekesek lehetnek. Fontos hangsúlyozni, hogy a vizsgálat alapvetốen a menedzsment és az EEM-terület képviselóire fókuszál: a szerzők különböző vezetőii szintek (felsô, közép- és alsó szint) és az EEM képviselöinek véleményét, észlelését ïtkö) ütköztetik, más szervezeti erintettek (pl. munkavállalók, Akszervezetek) véleménye nem jelenik meg.

A vizsgálat tanúsága szerint az EEM-terület képviselôi és a vállalatvezetés eltérő módon érzékeli és értékeli az EEM különbözó szerepeit, ezek tartalmát és fontosságát. A kutatás résztvevối által 36 kompetenciából összeállított fontossági listán mind a két csoportnál az etikusság a legmagasabb értékkel rendelkezó, legfontosabb kompetencia. Azonban amikor az egyes kompetenciák összefüggéseire alapuló, faktorelemzéssel létrehozott kompetenciamodelleket nézzük, a vezetés és az EEM-szakértôk által alkotott modellben már különbséget találunk. A vállalatvezetés kompetenciamodelliében az etikus viselkedés, a felelősségválla-

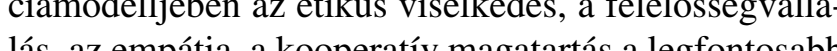
alapkompetenciák között jeln a a szel tes konágát az EEMterlut kepriselor joval hátráb sorolák, ezek szerin nem érzékelve ezeket az elvárásokat (vagy talán ezek nem valódi kôvetett gyakorlatot tükröznek, csupán vallott elvârások?). Osszzességében a kutatók értelmezése alapján a felső vezetók azt vallották, hogy az EEMvezető́kben és -szakértőkben egyaránt „érett és kooperatív partnert” keresnek, míg az EEM ,profi szolgáltatô" szerepben definiálta magát (amelynek, úgy túnik, nem meghatározó jellemzóje az etikusság).
A négy Ulrich- (1997) szerep (stratégiai partner, változási ügynök, érdekképviseló, adminisztratív szakértô) vonatkozásában a kutatás egymástól élesen eltérő ,„álapotot" rajzolt fel. Az adminisztratív szakértő szerepet az érintettek alapvető fontosságúnak érezték (az „elvá minimum"), ezzel kapcsolatban hasonló szerepelvárásokról számoltak be, és fejlődési lehetôségként a hatếkonyság fejlesztését jelölték meg. Ebben a szerepben különbségekról inkább egyes szervezeteknél - és nem általában - beszélhetünk. Egyes vállalatokban a vállalatvezetók fejében (és ennek megfelelóen a szerveze múködésben) az EEM-tevékenység be van zárva ebbe

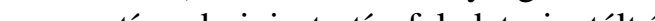
az operatív, adminisztrativ, felack tó szerepbe, az EEM szakentok azonban szeretnének innen kitorni (és leginkább a stratégiai partner, illetve a változási ügynök szerepek felé elmozdulni). Ebben szerepben az adminisztrativ rendszerek múködtetéséhez kapcsolódva megjelenhetnek etikai elvárások és kritérumok, mint például az igazságosság vagy a titoktartas kérdése, illetve ehhez kapcsolódva etikai konfliktusok is (pl. melyik vezetố, milyen adathoz juthat hozzá).

A stratégiai partner szerephez kapcsolódóan kevéssé elméleti, inkább gyakorlati dilemmák fogalmazódtak meg: minden érintett szeretné, ha az EEM jelentốsebben járulna hozzá a szervezet stratégiai döntéseihez, eltéró koordińta-rendszerekben és fognsäga szerin eltêrố koozin mindig úgy érzi, nem teljesíti ezeket az elvárásokat mindig úgy érzi, nem teljesíti ezeket az elvát és bizonyítania kell ezért a szerepért.

A változási ügynök szerepben élesen kirajzolódt
a A változási ügynök szerepben élesen kirajzolódtak a szerepben érzékelt belső ellentmondások. A gyakorlatban az EEM képviselói számára szintén egyértelmú, hogy a szervezeti változásokban vállalt aktív szerep, és ehhez kapcsolódva a munkaadói elvárások fókuszba helyezése nagyban rombolhatja az EEM iránti bizalmat (és konfliktusban lehet az érdekképviselő szerep elvárásaival), mégis ezekben a változásokban való aktív (optimális esetben proaktív) részvétellel az EEM kitörhet a csak adminisztratív szerepból, és elismerést vívhat ki. Ebben a szerepben (pl. jelentôs leépítéssel is járó vállalati átalakítás során) az érintettek elvárásai konfliktusba kerülnek egymással, és kérdés, hogy az EEM milyen fókussza, mennyiben képes, mennyire akarja egyáltalán ezeket az érintetti igényeket figyelembe venni.

A kutatás alapján leginkább gyengének értékelt, leginkább ellentmondásokkal terhes, zavaros elvárásokat hordozó szerep az érdekképviseló szerep. Egyik oldalról ebben a szerepben nagyon sok szinten és terïleten tapasztalnak érdekkonfliktust az EEM-menedzserek: sok helyzetben megjelenik a munkavállalók és vezetók konfliktusa (konkrét ügyekben, mint teljesítmény- értékelés, karrierlehetőségek, belső fegyelmi ügyek, illetve általános ügyekben, mint a kompenzáció vagy belsơ kommunikáció területe). De megjelennek náluk a közép-és felsó vezetók ellentétei is (pl. létszámok és orráselosztás). Az EEM-terület sok esetben közvetlenül felelós az érdekvédelmi szervezetek vs. vállalatvezetés közötti ellentétek kezeléséért (pl. bérmegállapodások, participáció). A használt metaforák sokasága és diverzitása (pl. tyúkanyó, bűnbak, hangulatfelelôs) is arra utalnak, hogy kevéssé tudják kiegyensúlyozni több forrásból származó, érzékelt és konstrúlt elváácok to a e gen illetve a sze helyzetekben a facilition, a donobiro, illetve a szovetséges szerep. A kutatás alapján jelentős problema, hogy a szervezeti érintettek kevéssé bíznak az EEM-ben: az alsó vezetók például úgy vélik, hogy egyértelmúen a felsố vezetés érdekeit szolgálják ki; technokrata, eredményorientált módon végrehajtják a felső vezetés utasításait.

Bokor és munkatársai (2005) ehhez a szerephez kapcsolódóan két stratégiát azonosítanak: a férfias és a nőies viszonyulást. A férfias stratégia képviselói viszszautasítják az „anyáskodó”, empatikus szerepet (vagy valakire áttolják a szervezeten belül a kotlós szerepet)ondolkodásuk és tevékenységük ebben a szerepben is EEM sto écen is

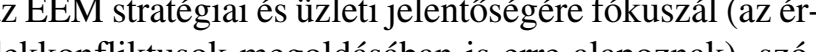
deklo használatukban is a verseny, a harc, a küzdelem dominál (reflektâlva a kemény EEM-felfogásra). A nőies stratégia képviselói törekednek arra, hogy részt vegyenek az emberi konfliktusok megoldásában, érzelmi támogatố s a kooperációra fókuszáló szerepet alkotva maguknak. ontos számukra az érintettek elvárásainak való megelelés, erre alapulva azonban sokszor kerülnek érzelmi (és nagy valószínúséggel morális) konfliktusba (inkább a szoft EEM-et követve). A két stratégia kombinációjaként Bokor és munkatársai egy harmadik, coach stratégiát is azonosítottak: e stratégia követôii elfogadják az emberi konfliktusok jelenlétét, de ezeken kívül maradnak Türodek jén kiépité zetók maguk képesek megoldani agy elkerilui ezeetôk maguk képesek megoldani vagy elkerülni ezeket a problémákat. Feladatukat a vezetés támogatáában és fejlesztésében, a szervezeti kultúra alakításában és a belkommunikáció fejlesztésében látják.

Végezetül fontos hozzátenni, hogy a Humán Tükör kutatás legutóbbi fordulója alapján (Bokor 2010) változatlan az érdekegyeztetố szerep gyengesége: probléma a bizalom és hitelesség szintje, illetve még a közép- és felső vezetés is úgy érzi, hogy az EEM alapvetően a felsố vezetôi érdekeket képviseli (erôsnek tartják az 
EEM-terület kontrollszerepét). A használt szerepmetaforák és ezek eltérései szintén érdekes képet adhatna az elvárásokról: az EEM-terület magát leginkább belsố tanácsadóként látja (41\%), ezt követi a vezérigazgató mellett álló szürke eminenciás szerep $(10 \%)$ a szolgálólány $(9 \%)$. A vezetốk szemében azonban belső tanácsadó metaforával (23\%) gyakorlatilag egy szinten van az adminisztrátor szerep (22\%). A szürke eminenciás szerep súlya mind az vezetôknél, mind az EEM-képviselônél azonos, 9\% (Bokor, 2010). Elsốre meglepó a Storey-modell szerepeinek (tanácsadó, renálólány) hangsúlyos felbukkanása. Kérdécses (ê

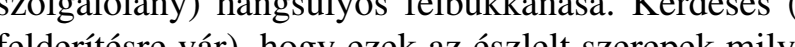
etikai tartalmat vagy „mellékzöngét” tartalmazhatnak?

\section{Végszó - etikus vagy etikátlan}

az emberierốforrás-menedzsment?

Az emberieróforrás-menedzsmentben a felbukkanó et kai kérdések és dilemmák összetettségük és súlyosságuk miatt adott etikai iskolára támaszkodva, szabályok alapján nehezen feloldhatók. Ráadásul sokszor nem egyértelmú a probléma értelmezése sem: gondoljunk például az egyik gyakran említett problémakörre, diszkriminációra. Mit jelent pontosan a diszkrimináció a szervezet szintién, és mit jelenthet az egyes EEMrendszerekben? Kire és milyen szempontok alapján kell vonatkoztatni a diszkriminációmentességet? Hogyan, milyen szempontok alapján lehet megkülönböztetni az észlelt és valós, a tudatos és tudatalatti diszkriminációt? Lehet-e egyáltalán szabályokkal megváltoztatni a helyzetet, megakadályozni a diszkriminációt? Maga fogalom meghatározása sem egyértelmú, pláne nem az a szervezeti alkalmazás, vagy egy adott helyzetre val lefordítás. Ráadásul a problémák jelentôs részében nehéz az esetleges döntések hatásait, eredményeit konkrétan számszerúsíteni, ami a szervezetben, a szerveze vezetése felé irányuló érvelést alapvetően nehezíti.

E problémás helyzetek jó, etikus megoldásairó sokszor nincs társadalmi konszenzus (pl. üvegplafon), illetve olyan globális gazdasági-társadalmi jelenségek beágyazódnak, amelyekból egyéni, vagy akár szervezeti szinten kevéssé látszik a kiút (pl. a kapitalista gazdasági berendezkedés, a kapitalista vállalati etika csapdái). Sokszor az egyes morális elvárások a gyakorlatban egymásnak is ellentmondanak: például a diszkriminációmentesség vagy a méltányosság kritériumai.

E morális helyzeteknek a komolysága, súlyossága nem elhanyagolható: a napi kérdések mellett jelen vannak az ismétlodó, halmozodó konfliktusok, és az EEM-tevékenység hatása nagyon sokszor közvetlenui érinti a vállalatnă dolgozó embereket és családjaikat.
Az egyének védekezési mechanizmusokat fejleszthetnek ki: elfásulnak, elidegenednek a problémától, a szabályok és szerepek mögé bújva elhárítják egyén felelôsségüket, teljesen azonosulhatnak a szerep valós vagy (vélt) elvárásaiva

Az etikai problémahelyzetek megoldásában, a megbirkózásban egyeni és szervezeti szinten is segíthet a szakmai diskurzus: az esetleges jó gyakorlatok, megoldások egymásnak való átadása és elemzése, a morális pluralizmus és a szervezeten belüli kommunikáció

\section{Lábjegyzet}

A tanulmány elkészítését a TÁMOP-4.2.1.B-09/1/KMR-2010-0005 program támogatta.

vásomban az emberierớforrás-menedzsment (EEM) és a magyar vallalati gyakorlatban meglehetősen elterjedt HRM (Human
Resource Management) kifejezést szinonimaként használom, törekedve a magyar elnevezés használatára.

Storey (1987) alapozó terminológiáját használva beszélhetünk az EEM kemény (hard) és puha (soff) változatáró́l (amelyek természetetesen a gyakorlatban nem feltétlenül különülnek el ilyen hangsúly az eróforrés-menedzsmenten, az eróforrások maximá lis hasznosít́śśn az erớforrás-szemléleten van a puha szemlélet fókusza inkább emberi eróforrás, az emberi tényező fontosságát hangsúlyozza. A kemény és puha EEM, vagy a kettó kombinációja az emberekhez való eltérố hozzáállást tükrözi, a szervezeten
belüli „,használatuknak” különbözô természetét, minôségét és mértékét jelenti.

A kemény EEM (szemléletében az utilitarista instrumentalizmus logikáját megjelenítve) teljesítménykö̈zpontú nézópontot takar, tevékenységek összessé́ge, amelyek az ïzletí stratégísamatok integrációban, és ennek céljait szolgálva múkö̈dnek. A meghatározó kemény modellek közül kiemelhetó a Fombrun és munkatársai által alkotott Michigani iskola stratégiai illeszkedési modellje (Fombrun et al.. 1984), illetve Schuler és Jackson New York modellje (Legge, 2005; Bratton - Gold, 2007). Ezekben a keretrendszerekben a munkavallaló egy azok kozul az eroforasok közul (mint a termófold, vagy a termelésben hasznalt gépek), amelyet menedzselni kell a strécéa szolgálataban, a maximális terclési eszközök: velük kapes Az enber mérhetốség, kalkulálhatóśág és kontroll. Az EEM-rendszerek személytelenek és a költséghatékony múködésre koncentrálnak: azaz a lehetó legolcsóbban biztosítani az éppen megfelelő menynyiségú és minőségư munkaerôt, a szervezet igényeinek megfelelő́n fejlesztve azt. Ebból a szempontból a munkavállalói viszony gazdasági tranzakcióként értelmezendó, amelyet megszünntethetnek, ha már nem kívánatos. A fokusz kimondottan az EEM stratégiai illeszkedésén, a racionalitáson, a kontrollon és a profitabiA kénény (PEM-gyakorlatra-fóleg az amerikai szaki áts, 2006). - elterjedt a teljesítményorient́llt munkavégzési rendszerek (high performance work systems) elnevezés is, amelyek alapvetốen olyan EEM-gyakorlatokra koncentrálnak, amelyek közvetlenül (és igazoltan) kapcsolatba hozhatók a penzzügyi eredményességgel (pl. ösztönzố bérezés, belsô toborzás) (Legge, 2005: p.19.).
A puha EEM szemléletében a fejlesztói humanizmusra támaszkodik; az amerikai szakirodalom szóhasználatában elkötelezettsészéssel is találkozunk. A puha irányzatban az EFM-tevékenység arra koncentrál hogy a munkavállaláók elkötelezettséóére, lojali ițsára alapozva biztosítson a vállalat számára tartós versenyelóny A puha EEM is elkötelezett az üzleti célok teljesítése mellett, de a munkavállalókat nem passzív, hanem aktív, kreatív és fejlódésorientált, a döntések meghozatalára képes és bizalomra érdemes egyéneknek tekinti, akiknek a szervezet iránti elkötelezettsége, megfeleló moivaciora es kon serilagos A szervezeti versenyelóny a munkavállalók kreatív entathatón. és a döntésekbe való bevonósukból származik (Pinnington et al., 2007). A puha EEM fontos fókusza a fejlesztés, egyéni szinten az egyéni fejlódési lehetőségek szervezeti kereteinek biztosítás (képzések, munkavégzési rendszer és munkakörülmények megfelelô kialakítasa, munkavallalơi részvétel), szervezeti szinten pedig a szervezeti kultúra fejlesztêse. A puha modellek kozzul a szakirodalom kiemelni a Harvard többszörös érintett modellje Beer et al., 1985), illetve a részben rá épüló Wryol (Hendry - Pettigrew, 190, Bratton - Gold, 2007).

(a) elméletét és kutatási irányzat́st. A minstream EEM-pa jelle alapjai az Egyesült Államokból származnak (Legge, 1998; 2005), domináns irányzata gyakorlatorientált, alapvetó́n elốír jellegú, általában praktikus tanácsok és empirikus adatok bemtatására törekszik, és a legjobb, leghatékonyabb megoldások bemutatására koncentrál. Alappelteveseiben racionálisan múködo, saját stratégiai céljaikat követő szervezeteket feltételez, amelye az egyensulyi allapotra torekednek, es amelyekben a menedzsment alapvetó feladata a munkaválalabkat a hatékonyságra, és

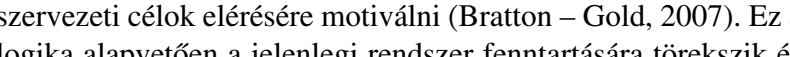
funkcionalista megközelitést tïkröz, ami úgy tekint az EEMmint a szervezeti célok eléréśnek mechanizmuśrá ísy a klózszikus menedzsmentelméletek fejlő́dés- és hatékonyságközpotúságát tükrözi (Greenwood, 2002).

Az EEM kritikai iránya nagyrészt az Egyesült Királyságb származik, ahol az 1980-as évekre tehetó a kritikai vizsgálód kezdete (Legge, 2005; Guest, 2007). A kritikai irány fóleg a hatalom, a kontroll, a konfliktusok, a legitimitás kerdeseit és hatását vizsgâjja az EEM-tevékenységben. A kritikai álláspont EEM-et retorikai fogasnak és manipulatívnak tartja, a vezetöses et azzal vádolják, hogy újradefiní́lja a munka jelentését és a szervezet-munkavállaló kapcsolatát, hogy elfogadtassa a létezó és nem tolerálható gyakorlatokat (pl. az igazságtalan bérezés, a munkavállalók félrevezetését). A szerzók az EEM-re mint az egyéneket tárgyiasitó gyakorlatok összességére (Towney, 1993), az ellenállás és a konfrontáció elnyomására (Sennett, 1998), azaz rôviden a munkaválalalok manipulálasañak eszkozzere tekintenek, kevéssé leíró, sokkal inkabb ertékeló modon. Hart szélsőséges kritikát fogalmaz meg az EEM-ról: „Az EEM-et nemcsak amo

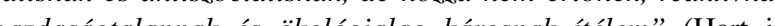
Stayaert Jansens, 1999: p. 185.). A mainsteam (Hzerzók szemben a kritikai írók (akik szintén több irányzatba sorolhatoa) a munkahely természetének pluralizmusát (többfajta érintet és azok érdekekeinek, céljainak legitim jelenléte) és kollektivis természetét helyezik a fókuszba. Úgy gondolják, hogy a munlehetnek, ezért potenciálisan más célokkal rendelkeznek, amelyeket a szervezeteknek stratégiai és taktikai szinten egyaránt figyelembe kellene venni. A kritikai EEM-iskola elméleti alapjaiban egyértelmúen támaszkodik olyan múhelyekre, mint a frankfurti iskola (Adorno, Habermas), Derrida, Foucault gondolatai, kötódik tovabbá a kritikai menedzsment (pl. Alvesson - Wilmott, 1996), kritikai pedagógia (pl. Freire, 1996) irányzatokhoz, és szembehelyezkedik a mainstream irányzatok pozitivista nézópontjával. A kritikai EEM irányzata kapssolódik majd az etika és A klassikus utiltariz

us egyik atyja, Jeremy Bentham megfogalmazásában „A Természet az emberiséget „két szuverén úr, a Egyik oldalról a jó és a rossz meghatározása, másik oldalról az okok és okozatok lánca az ô trónusukhoz van erósitve" (Bentham, 1983). Benthan logikajaban barmely tevekenyseg helyesseget vagy helytelenségét, erkölcsösségét az határozza meg, hogy mennyiben hasznos, azaz mennyire hoz létre boldogságot, élvezetet, oromôt. A kôzossség érdeke pedig nem más, mint hogy az adontham törekvése olyan racionális és logikus, ́́tl'́tható legyen. létrehoźsa volt, amelynek célja - a korabeli angliai politikai elit tradíciókon és privilégiumokon alapuló, korrupt és átláthatatlan, kevesek érdekét szem elót tartó irányitúsi rendszerével ellentétesen - a „legnagyobb boldogság elérése a lehetố legtöbb ember számára" (persze ez nem jelenti azt, hogy mindenki egyenlő mértékben részesül belôle).

Arisztotelész erényetikai rendszerének középpontjában az emberi cselekvés mint valamilyen cél, eredmény érdekében végrehajtot cselekvés all. Az emberi cselekvés végsó̉ célja a legfóbb jó, az eudalyek olyan képeśrek, amelyek által urakenben ôlt testet, kon, és bizonyos helyzetekben ésszerúen, a leghelyesebb módon cselekszünk azaz nem pusztán lelki alkat, de maga a cselekvés is. Az erény ,középhatár két rossz között, melyek közül az egvik túlzásból, a másik a hiányosságból ered" (Arisztotelész, 1971: p.43.). Az erényeknek két osztálya különíthetô el: észbeli és etikai erények. Fontos, hogy az erények olyan jellemvonások, amelyek (1) magukba foglajják az akaratot, igy élesen elkülönülnek más szemelyes tulajdonsagokoktól, mint az intelligenciától vagy az egészségtốl, (2) gyakorlással, ceeltudatos neveléssel fejleszthetók „Tehát nem tiormészetố, de nem is természet ellenére fejlódnel megalkotva, hogy befogadjuk óket, viszont a szoḱs által lehetünk bennük tökéletesek” (Arisztotelész, 1971: p. 32.).

Kant (2004) rendszerében az erkölcsi cselekvést a vezérló alapelv minősitit, azaz egy adott tett indítóoka sokkal fontosabb, mint a tett maga, vagy a kōvetkezménye. Az egyen rendelkezik á laszthat. Válaszzási lehetớsége van azonban hajlamai, motiváció kôvetése vagy kötelességei közül, illetve rendelkezik a racionáli gondolkodás képességével. A kötelesség pedig olyan cselekedet, amelyet az egyén az erkolcsi törvénynek való önkéntes engedelnális lényre kötelezó érvényú, azaz univerzális, (2) kategorikus, azaz nem korlátozza feltétel, (3) az emberi gondolkodás produktuma, az észból ered (4) nem érzelmeken, érzéki tapaszztalatokon vagy vágyon alapul. Kant kategorikus imperatíivusza: Cselekedj 
úgy, hogy az emberségre, mind a saját személyedben, mind bárlegyen szükséged" (idézi Hársing, 2001: p. 136). Ezt a kategoikus, azaz morális imperatívuszt (azaz hogy az embert soha nezabad eszközként kezelni) élesen meg kell különböztetni a sok hipotetikus imperatívusztól, amelyek konkrét utasítást fogalmaznak meg egyes állapotok elérésére vagy elkerülésére. A feminista etika képviselójeként Gilligan koncepciójában az alapvető̉en férfias vonásokon (mint igazsáág, racionalitás) alapul moralitás mellett megkülönböztet inkább nő́i vonásokon nyugvó

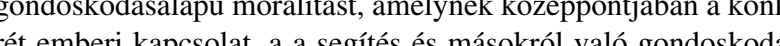
áll. A férfi és nói moralitás más-más logikár épül, gnkább kiegószíti, semmint kizárija egymást (Tong, 2005).

\section{Felhasznált irodalom}

Ackers, P. (2009): Employment ethics. in: T. Redman - A. Wilkinson (eds): Contemporary Human Resource Management. London: Prentice Hall, p. 450-471.

Alford, H.J. - Naughton, M.J. (2004): Menedzsment, ha számít a hit. Keresztény társadalmi elvek a modern korban. (Managing as if Faith Mattered: Christian Social Principles in the Modern Organisation). Budapest: Kairosz

M, M. - Willmott, H. (1996): Making Sense of Management: a critical introduction. London: Sage

Arisztotelész (1971): Nikhomakhoszi etika (Nicomachean

Bauman, Z. (1993): Postmodern ethics. Oxford: WileyBlackwell

Bentham, J. (1983): Deontology; together with a table of the springs of action; and the article on utilitarianism. Oxford: Clarendon Press

Beer, M. - Lawrence, P. - Mills, D. - Walton, R. (1985): Human Resource Management. New York: Free Press Bokor A. (2010): HR Tükör Kutatási eredmények (HR Mirror Research results). Budapest: (kézirat)

Bokor A. - Bíró K. - Kováts G. - Takács S. - Toarniczky A. (2005): Humán tükör - körkép a hazai szervezetekben a HR-tevékenységre vonatkozó elvárásokról és anna megítéléséról I. (HR Mirror - picture of definitions and expectations towards $\mathrm{HR}$ activity in Hungary $\mathrm{I}$ ). Vezetéstudomány, 36(1), p. 33-47.

Bokor A. - Bíró K. - Kováts G. - Takács S. - Toarniczky A. (2005): Humán tükör - körkép a hazai szervezetekbe a HR-tevékenységre vonatkozó elvárásokról és annak megítéléséról II. (HR Mirror - picture of definitions and expectations towards HR activity in Hungary II.). Vezetéstudomány, 36(2), p. 16-31.

Bokor A. - Szóts-Kováts K. - Csillag, S. - Bácsi K. - Szzilas R. (2007): Emberieróforrás-menedzsment (Human resource management). Budapest: Aul

Bolton, S. - Houlihan, M. (2007): Searching for the Human in Human Resource gement. Theory, practice and workplace context. New York: Palgrave Macmillan

Boxall, P. - Purcell, J. (2007): Strategic Management and Human Resources: the pursuit of productivity, flexibility and legitimacy. in: A. Pinnington - R. Macklin - T. Campbell (eds): Human Resource Management. Ethic

Bowie, N. (2002): The Blackwell Guide to Business Ethics. Oxford: Blackwell Publishing

Th, J. - Gold, J. (2007): Human Resource Management Theory and Practice. London: MacMillan

Celvarajan, T. (2006): Beyond rhetoric and bureacracy. Using HRM to add Ethical Value. in: J. . Decticut: Information Age Publishing p. 71-85. Cio W. (2009): Managing Hue Peshing, p. 71-85. Cascio, W. (200).Managing Human Resources. Productivity quality of work life, profits. Singapore. Mc Graw-Hill

. $R$. a

of S. - Naughton, M. (2002): Rethinking the purpose

Crane, A. - Matten, D. (2007): Business Ethics. Oxford: Oxford University Press

Dachler, H.P. - Enderle, G. (1989): Epistemological and ethical consideration in implementing and human resource management. Journal of Business Ethics, $p$. 97-606

De Cieri, H. - Kramar, R. (2005): Human Resource Management in Australia: Strategy, People, Performance. North Ryde, N.S.W: McGraw Hill

Deckop, J. (2006): Human Resource Management ethics. Greenwich, Connecticut: Information Age Publishing

Delbridge, R. - Keenoy, T. (2010): Beyond managerism? The International Journal of Human Resource Management, 21(6), p. 799-817.

Fisher, C. (1999): Ethical stances: the perception of accountancy and HR specialists of ethical conundrums at work. Business Ethics: A European Review, 8(4), p. 236-248.

C. Tichy, N. - Devanna, M. (1984): Strategic Human Resource Management. New York: John Wiley Feeman, E. (1984): Strategic management, stakeholder approach. Oxford: Pitman Publishing

reire, P. (1982): Creating alternative research methods: Learning to do by doing it. in: B. Hall (ed): Creating knowledge: a monopoly? New Delhi: Socity for Participatory Research in Asia, p. 29-37.

Greenberg, J. (1993): The social side of fairness: interpersonal and informational classes of organizational justice. in: Cropanzano, R. (ed.): Justice in the Workplace: Approaching Fairness in Human Resource Management. Hillsdale, NJ: Lawrence Erlbaum, p. 79-103.

Greenwood, M.R. (2007): Ethics and Human Resource Management. in: H. De Cieri - R. Kramar (eds): Human Resource Management in Australia. Australia: McGrawHill Australia, p. 562-587.

Greenwood, M.R. (2002): Ethics and HRM. A review and conceptual analysis. Journal of Business Ethics, 36(3), p. 261-278.
Greenwood, M.R. - De Cieri, H. (2007): Stakeholder Theor and the Ethics of HRM. in: A. Pinnington - R. Mackl Employment and Ethics. Oxford: Oxford University Employment and

Guest, D. (2007): HRM and performance: can partnership address the ethical dilemmas? in: A. Pinnington R. Macklin - T. Cambell (eds). Human Resource management. Ethics and employment. Oxford: Oxford University Press, p. 52-65.

Hársing L. (2001):Az európai etikai gondolkodás (The European Ethical Thought). Szeged: Bíbor Kiad

Hegedüs Z. (2010): A menedzser bibliája (The Bible of the manager). Budapest: Kairosz Kiadó

Hendry, C. - Pettigrew, A. (1990): Human Resource Management: An agenda for the 1990s. Internation Journal of Human Resource Management, 1(1), p. 17 42

Jackall, R. (1988): Moral Mazes. Oxford: Oxford University Press

Johnson, C. (2007): Ethics in the workplace. London: Sage

Johnson, E. (1995): Shaping our economic future: dignily in the workplace. in: M. Stackhouse (ed): On mor business. Michigan: Wm. B. Erdmans Publishing, p. 649-653.

Kant, I. (2004): A tiszta ész kritikája. Budapest: Atlantisz

Knights, D. - Willmott, H (1999): Management lives. London: Sage

Koehn, D. (2002): Ethical Issues in Human Resources.in: N. Bowie (ed): The Blackwell Guide to Business Ethics. Oxford: Blackwell Publishing. p. 225-243.

Kujala, J. - Pietilainen, T. (2007): Developing Moral Principles and Scenarios in the Light of Diversity: An Extension to the Multidimensional Ethics Scale. Journ of Business Ethics, 70(2), p. 141-150.

Legge, K. (1998): Is HRM ethical? Can HRM be ethical? in: M. Parker (ed): Ethics and organisations. London: Sage, p. $150-172$.

Legge, K. (2005): Human Resource Management. Rhetorics and Realities. New York: Palgrave

Lepak, D. - Colakoglu, S. (2006): Ethics and strategic huma resource management. in: Deckop (ed): Human Resource Publishing, p. 27-45.

Martin, G. - Woldring, K. (2001): Ready for the mantle? Australian HR managers as stewards of ethics. International Journal of Human Reso urce Management 12(2), p. 243-255.

Mathis, R. - Jackson, J. (2006): Human Resource Management. Boston: Thompson

cIntyre, A. (1997): Az erény nyomában (After Virtue). Budapest: Osiri

Montemayor, E. (2006): Fairness and reciprocity. in: J. Deckop (ed): Human Resource Management Ethics. Connecticut: Information Age Publishing, p. 195-216.
Murphy, J. - Pyke, D. (2002): Humane work and the challenges of work design. in: S. Cortright $-\mathrm{M}$. Naughton (eds): Rethinking the purpose of business. Indiana: University of Notre Dame, p. 289-310.

O'Higgins, E.-Kelleher, B. (2005): Comparative Perspectives on the Ethical Orientations of Human Resources, Marketing, and Finance Functional Managers. Journal of Business Ethics, 56(3), p. 275-288.

Orlitzky, M. - Swanson, D. (2006): Socially Responsible Human Resource Management. in: Deckop (ed): Human Resource Management Ethics. Greenwich, Connecticut: Information Age Publishing, p. 3-24.

Pasmora, W. (1999): A hero for the underdogs: A review of Dave Ulrich's Human Resource champions. Organization, 6(2), p. 361-369.

Pinnington, A. - Macklin, R. - Cambell, T. (2007): Introduction. in: A. Pinnington - R. Macklin - T. Campbell (eds): Human Resource $\mathrm{M}$ and Employment. Oxford: Oxford University Press, p.

Schumann, P. (2001): A moral principles framework for human resource management ethics. Human Resource .

Sennett, R. (1998): The corrosion of a character. New York: W.W. Norton \& Company

Steyaert, Ch. - Janssens, M. (1999): Human and Inhuman Resource Management: Saving the Subject of HRM. Organisation, 6(2), p. 181-198.

Storey $J$ (1987): Development in the management of human resources: an interim report. Warwick papers in IR. Coventry: University of Warwick

Storey, J. (1992): Developments in the management of Human Resources. Oxford: Blackwell

Szóts-Kováts K. (2006): Merre tart az emberi eróforrás menedzsment? (Where are you going, HRM?

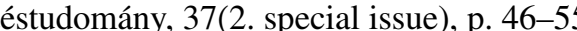

Tong, R. (2005): Feminist Ethics. in: P. H. Werhane - R. E. Freeman (eds): The Blackwell Encyclopedia of Management. Business Ethics. Oxford: Blackwell Publishing, p. 191-196.

Torrington, D. - Hall, L. (1998): Human Resource Management. London: Prentice Hall Europe

Towney, B. (1993): Foucault, Power/Knowledge and Its Relevance for Human Resource Management. Academy of Management Review, 18(3), p. 518-545.

Jich, D. (1997): Human Resource champions. Boston, Massachusetts: Harvard Business School Press

Ulrich, D. - Beatty, D. (2001): From partners to players: extending the HR playing field. Human Resource Management, 40(4), p. 293-307.

Wasieleski, D.M. - Weber, J. (2009): Does Job Function Influence Ethical Reasoning? An Adapted Wason Task Application. Journal of Business Ethics, 85(Suppl. 1) p. 187-199.

Weaver, G.R. - Trevino, L.K. (2001): The role of human resources in ethics/compliance management: a fairness 
perspective. Human Resource Management Review, 11(1-2), p. 113-134.

Werhane, P.H. - Radin, T. - Bowie, N.E. (2004): Employment and Employee Rights. Foundation of Business Ethics. UK.: Blackwell Publishing

Wiley, C. (1998): Reexaminating perceived ethics issues and ethics roles among employment managers. Journal of Business Ethics, 17(2), p. 147-161.
Wooten, K. (2001): Ethical dilemmas in human resource management: an application of a multidimensional framework, a unifying taxonomy, and applicable codes. Human Resource Management Review, 11(1-2), p. 159-175.

Wray-Bliss, E. (2007): Ethics at work. in: D. Knights - H. Willmott (eds): Introducing Organisational Behaviour management. UK.: Thompson Learning, p. 506-533.

\section{Szerzőinknek}

A Vezetéstudomány a Budapesti Corvinus Egyetem Gazdálkodástudományi Karának havi, referált folyóirata. A lapban a vezetési és gazdálkodási tudományterületekhez kapcsolódó témakörök elméleti és gyakorlati kérdéseit elemző és vizsgáló írások jelennek meg. A szerkesztôség (robert.becsky@uni-corvinus.hu) elektronikus formában kéri az írásokat.

A cikkeket elektronikus levélben (MS Word fájl formátumban) lehet a szerkesztôséghez eljuttatni. A Vezetéstudományban megjelent cikkek magyar és angol nyelvú összefoglalói elérhetőek a http://www.vezetestudomany. hu és a http://vezetestudomany.hu címeken.

A lap tudományos folyóirat, ezért szövegközi forráshivatkozások és ezek jegyzéke nélküli írásokat nem jelentet meg. A Vezetéstudományban megjelentetni szándékozott kéziratok szerzóitól az alábbi követelmények figyelembevételét kérjük:

- A cikkek szokásos terjedelme a hivatkozásokkal, ábrákkal és táblázatokkal együtt 20-24 oldal, 1,5-es sortávolsággal (12-es betúméret, Times New Roman betütípus).

- A cikkek elsô oldalának alján tüntessék fel a szerzô foglalkozását, munkahelyét és beosztását, elektronikus levelezési címét, a tanulmány elkészítésével kapcsolatos információkat és az esetleges köszönetnyilvánításokat.

- A kézirathoz csatolandó egy magyar nyelvú és lehetôség szerint egy angol nyelvú rövid összefoglaló (200 szót nem meghaladó terjedelemben), valamint a cikk fő témaköreit megnevezô kulcsszavak jegyzéke.

- Kiemeléshez félkövér és dólt betú használható, aláhúzás nem. Jegyzeteket lehetóleg ne használjanak, amennyiben azok feltétlenül szükségesek, szövegvégi jegyzetként adják meg.

- A táblázatoknak és ábráknak legyen sorszáma és címe, valamint - átvett forrás esetén - pontos hivatkozása.

- Az ábrákat és a táblázatokat a kézirat végén, külön oldalakon, sorszámmal és címmel ellátva kérjük csatolni, helyüket a szövegben egyértelmúen jelölve (pl. „Kérem az 1. táblázatot kb. itt elhelyezni!”).
- A szövegközi bibliográfiai hivatkozásokat zárójelben, a vezetéknév és az évszám feltüntetésével kérjük jelölni: pl. (Veress, 1999); szó szerinti, idézójeles hivatkozás esetén kiegészítve az oldal(ak) számával (pl. Prahalad-Hamel, 1990: 85.).

- Amennyiben egy hivatkozott szerzőnek több bibliográfiai tétele van ugyanazon évben, ezeket 1999a, 1999b stb. módon kell megkülönböztetni.

- A felhasznált források cikk végén elhelyezett jegyzékét ábécérendben kérjük, a következő formában:

1. példa (könyv): Porter, M.E. (1980): Competitive Strategy; New York: The Free Press

2. példa (folyóiratcikk): Prahalad, C.K. - Hamel, G. (1990): The Core Competence of the Corporation; Harvard Business Review, május-június, 79-91. o.

A formai követelmények fentiekben érvényesített, ún. „Harvard” rendszeréról (más néven „szerzólév” vagy „név/dátum” hivatkozási módszerról) részletes tájékoztatást nyújtanak az alábbi WEB-címeken elérhetô források.

Havi folyóirat lévén és a megjelenés átfutási idejének csökkentése érdekében a Vezetéstudomány kefelevonatot nem küld, elfogadás előtt azonban a szerzóknek egyeztetés céljából elküldi a cikk szerkesztett változatát.

2009. januártól a Vezetéstudományban publikált cikkek elérhetőek az ISI Eme „www.securities.com” internetcímen található strukturált on-line információs adatbázisban. 2009 júniusától a Vezetéstudományban közölt írások elérhetőek az EBSCO Academic Search Complete adatbázisában a http://web.ebscohost.com/ ehost $/$ search ?vid $=20$ \& hid $=102 \&$ sid $=747$ a $764 f-362 f$ 4683-9255-4e54f5ba0df7\%40sessionmgr112 oldalon is.

2012 március 1.-tôl a Vezetéstudomány egyes cikkei elérhetốk a http://unipub.lib.uni-corvinus.hu/500/ oldalon is.

Külön kívánságra 2004-ig visszamenóleg az összes korábbi kiadás publikációit elektronikus változatban is elküldjük. Ha a szerző nem járul hozzá cikkének eseti kérésre, elektronikus úton való továbbadásához, kérjük, előre közölje ezt. 